Panteleyev A. F. Dolmatova A.S.

\title{
SUPERLATIVE IN THE POETRY OF MARINA TSVETAYEVA
}

1) $\mathrm{PhD}$ in linguistics, associate Professor. Southern Federal University 105,Bolshaya Sadovaya, Rostov-on-Don. 344002, Russia. E-mail:AF3@yandex.ru 2) assistant of Department of Russian language for foreign students. Southern Federal University 105, Bolshaya Sadovaya, Rostov-on-Don. 344002, Russia. E-mail: flomasteri@mail.ru

\begin{abstract}
This article deals with the research of functioning of superlatives as the means of creating expressive intensity and expression in the language of Marina Tsvetayeva's poetry. Synthetic forms of the superlative degree of adjectives take an important place among the means of expressing in the works by Tsvetayeva. A specific feature of Marina Tsvetayeva's poetry is the usage of synthetic forms in the constructions where a simple form of superlatives is governed by a noun in the genitive case with the preposition «из».The presence of a prepositional-case word form allows to convey the absolute degree of demonstration of the character in the subject brighter, focus the recipient's attention on the highest degree of characteristic's intensity.

Marina Tsvetayeva's poetry is also characterized by using in these structures the attributive pronoun «весь» in the plural form. The use of the attributive pronoun emphasizes that this comparison has the character of a full coverage of the compared objects. It indicates brighter that the sign is manifested at the highest level, despite of the large number of things, which are associated with the subject (which has this feature).

A distinctive means of creating expressiveness in Tsvetayeva's lyrics is the use of occasional synthetic forms of superlative adjectives. These appear in the form of adjectives in which the semantics does not allow the formation of the superlative degree of comparison.
\end{abstract}

Key words: adjective; superlative; comparative; expressiveness; intensity; synthetic forms

Пантелеев А.B., Долматова А.C.

\section{СУПЕРЛАТИВ В ПОЭЗИИ МАРИНЫ ЦВЕТАЕВОЙ}

Expressiveness as one of the features of the language unit is closely connected with the category of emotional evaluation and with expression of human emotions on the whole. Many genetically fixed expressive means of language, including tropes and figures of speech, as well as techniques for structuring a verse, ascend to the peculiarities of presentation of an utterance in an emotionally coloured (effective) speech. This explains the similarity of the arsenal of expressive devices and principles of their functioning in the languages of different systems. It is significant that the categories of expressiveness and emotionality in the works of a number of linguists are identified [2, p. 591]. Ye. M. Galkina-Fedoruk believes that «expression is an intensification of expressiveness, increasing of effecting force of the said» [1, p. 107]. To convey expressiveness, language resorts to different level means that represent such level-forming branches of language as phonetics, lexicology, morphology and syntax. The grammatical interacts at that with the lexical. Besides the informative function, in the literary text the «expressive» function is more realized [3]. This article attempts to analyze the specific character of functioning the synthetic forms of the superlative degree of comparison of adjectives as the means of creating expressiveness in the language of M.I. Tsvetayeva's works.

Analyzing the examples of using the superlative degree of comparison of adjectives in the poetry by Marina Tsvetayeva, it should be noted, first of all, the regularity of using such forms in the language of poetess's works. In the collection of selected works by Tsvetayeva by continuous sampling we have revealed 72 examples of using the forms of the superlative degree of comparison of adjectives, which accounts for than $60 \%$ of the general number of usages of various forms of degrees of comparison of adjectives in the language of Tsvetayeva's lyric poetry. Therefore, one can argue that the superlative degree of adjectives for the author is more preferable means of expressing intensity and expressiveness. 
In so doing, the synthetic form of the superlative degree of comparison of adjectives in the texts of poems has been found 57 times, which accounts for almost $55 \%$ of the total number of using the forms of the degrees of comparison of adjectives in the language of Marina Tsvetayeva's lyric poetry. The use of the synthetic form of superlative degree of comparison of adjectives on the whole can be considered the most characteristic for the author's poetry, which disproves the thesis about certain bulkiness of the synthetic form in comparison with the analytical form of the superlative and, consequently, about less preferable use of simple form of superlative degree in the poetic texts [6].

Synthetic form of the superlative degree of comparison of adjectives renders a higher degree of intensity of character as opposed to synthetic form of the comparative degree [9]. Its use reflects a subjective character of Tsvetayeva's poetry, high degree of emotionality, expressiveness of the poetess's lyric poems.

In the first place, the use of these forms in constructions in which a simple form of the superlative degree governs the noun in genitive case with the preposition «из» attracts attention, compare: «Строжайшее из зерцал!» (the strictest of the mirrors) (Tsvetayeva. Мой письменный верный стол/My faithful desk).

In this example, the form of the adjective «строгий»(strict) means the feature which in the article «зеркало» (mirror) is manifested in the superlative degree in comparison with its manifestations in all the other homogeneous articles. It is indicated by the form of the genitive case of the noun «зерцало» with the preposition «из». We have revealed 16 examples of using the construction «synthetic form of the superlative degree of adjective + noun in the genitive case with the preposition «из»»), which accounts approximately for one third of the total number of the uses of synthetic forms of this degree of comparison of adjectives, compare: «O, откровеннейшее из сокровищ:// Порода - узнаю тебя» (Tsvetayeva. EX - CL - DEVANT); «Ты дробью голосов ручьевых// Мозг бороздишь, как стих. // (Вместительнейший из почтовых// Ящиков - не вместит!)» (Tsvetayeva. Строительница струн - приструню и эту / Organizer of the Strings - will tune up this one).

Such constructions for the author are obviously to be extremely important, as the presence of prepositional and case word-form allows to convey the absolute degree of manifestations of the feature in the article brighter, to have the highest degree of intensity of a feature accentuated for the addressee of information. It is characteristic by no chance for Marina Tsvetayeva's lyric poetry the use of attributive pronoun «весь» in the form of plural in such constructions, compare: «У тяжелейшей из всех преступниц// Сколько заступников и заступниц...» (Tsvetayeva. Люди на душу мою льстятся / People are tempted with My Soul).

The use of the attributive pronoun emphasizes that this comparison has the character of full coverage of the compared items. The feature of «преступница» (offender) is displayed in the highest degree as compared with its manifestations in the other items of one family designated as «преступница». The degree of intensity of manifestation of the feature in such combination is undoubtedly higher by far than in the construction «тяжелейшая преступница», compare: «Оты - из всех залинейных нот // Нижайшая! - Кончим распрю!» (Tsvetayeva. Последний моряк / The Last Sailor).

On the other hand, the use of the attributive pronoun «весь» in plural accentuates that the feature is manifested in the highest degree despite a great number of the things with which the given item with the same feature is contrasted, compare: «Чужая кровь - желаннейшая // И чуждейшая из всех!» (Tsvetayeva. Магдалина / Magdalena).

The following peculiarity of using synthetic forms of the superlative degree of adjectives in the language of Marina Tsvetayeva's works is the author's endevour to saturate the poetic text with such forms. It is characteristic for Tsvetayeva to use a single synthetic form, but one can often find the examples of realization of these forms in one context, compare: «Из всех страстей// Страстнейшая,// Из всех смертей// Нежнейшая» (Tsvetayeva.Памяти Т.Ф. Скрябиной / In Memoriam T. F. Skryabina); «Ha заре наимедленнейшая кровь,// На заре наиявственнейшая тишь...// Око зрит невидимейшую даль,// Сердце зрит невидимейшую связь...// Ухо пьет неслыханнейшую молвь» (Tsvetayeva. На заре наимедленнейшая кровь / At Dawn - the slowest Blood).

Representing each of the features as the highest by the degree of its manifestation, the author of the poems tries to achieve a maximum degree of expressiveness of the text. It is possible to argue that these forms perform text-forming function, are the means of expressing the category of text coherence [5]. It is essential to note that each of the forms of the superlative degree denotes the highest degree of manifestation of a characteristic in a certain object, that is, each of the definitions expressed by such 

и прикладной лингвистики». - T.1, №4(6), 2015.

forms has a supporting word - a noun (or a word that substitutes it). Thus, a high degree of text saturation with information is achieved, at the same time, this information contains expressiveness and the idea of extremely high degree of intensity of manifestation of different signs in different items.

In the lyric works by Marina Tsvetayeva there are less examples of using the forms analyzed as homogeneous parts of the sentence, compare: «Чужая кровь - желаннейшая // И чуждейшая из всех!» (Tsvetayeva. Магдалина / Magdalena).

It is evident that the degree of information value and expressivity of such constructions is nevertheless lower than in the above analyzed constructions. On the other hand, one can note that the use of homogeneous parts of the sentence - synthetic forms of the superlative is inherent in Tsvetayeva's poetry in the cases when the author characterizes not an object of artificial nature but a human, compare: «He тот - высочайший,// С усмешкою гордой: // Кротчайший Георгий,// Тишайший Георгий,// Горчайший - свеча моих бдений// Георгий, Кротчайший - с глазами оленя - Георгий!» (Tsvetayeva. О всеми ветрами Колеблемый лотос! / With All the Winds Swaying Lotus!).

Analyzing this example, it should be underlined that it is characteristic for Tsvetayeva to use a technique of repetition of a synthetic form within the framework of one context, grammatical and lexical repetition which can be found in the following constructions, compare: «Из всех страстей// Страстнейшая, ...» (Tsvetayeva. Памяти Т.Ф. Скрябиной); «И шаг, и светлейший из светлых// Взгляд - коим поныне светла» (Tsvetayeva. Петр и Пушкин / Peter and Pushkin).

Stress should be also laid on the fact that most of the adjectives used in the synthetic form of the superlative degree of comparison in the analyzed poems indicate not external but internal characteristics of an object associated with intellectual, spiritual, psychological constituents of life of a man and his perception of the objective world, compare: «Грех последний, неоправданнейший!» (Tsvetayeva.От родимых сел, сел! / From Native Villages, Villages!); «И шаг, и светлейший из светлых// Взгляд - коим поныне светла» (Tsvetayeva. Петр и Пушкин ? Peter and Pushkin); «Такой уж почет, что ближайшим друзьям - Нет места...» (Tsvetayeva. Нет, бил барабан перед смутным полком / No, One Beat the Drum before the Anxious Regiment); «Кого ж это так - точно воры вора// Пристреленного выносили? // Изменника? Нет. С проходного двора - // Умнейшего мужа России» (Tsvetayeva.
Нет, бил барабан перед смутным полком / No, One Beat the Drum before the Anxious Regiment).

The description of external characteristics of the thing expressed by the adjective in synthetic form of the superlative degree of comparison is the least likely to find in the texts of Marina Tsvetayeva's verses, compare: «Темнейшее из ночных// Мест: мост. - Устами в уста!...» (Tsvetayeva.Ночные места / Night Places). But in this case, the adjective denoting external feature of the object - colour, is represented in one context with the superlative of «вернейшая» (the most faithful), denoting the sign of the name «смерть» (death), ср.: «Вернейшее из ночных// Мест - смерть!» (Tsvetayeva. Ночные места / Night Places).

In another example the adjective denoting colour realizes a metaphorical figurative meaning in the context, compare: «Что мне делать, певцу и первенцу,// В мире, где наичернейший - сер!» (Tsvetayeva. Что же мне делать, слепцу и пасынку / What's to do, to me, blind and stepchild). The adjective «серый» (grey) in this context realizes the following meaning: «Dull...3. Mediocre, absolutely unremarkable» [7, p. 738]. Hereupon the adjective «черный» (black) in synthetic form of the superlative degree of comparison is perceived as not colour designation but description of a man's character, his nature.

It is also necessary to note that Tsvetayeva's poetry is featured by synthetic forms of the superlative degree of adjectives, the semantics of which is connected with the state of stillness, calm, meekness, fragility. Compare: «За тишайшую просьбу уст их, // Исполняемую как окрик» (Tsvetayeva.Хвала богатым); «Смысл выше ниже тон,// Ни-жайший...» (Tsvetayeva. Крысолов); «Наинасытнейшая рифма// Недр, наинизший тон» (Tsvetayeva. Емче органа и звонче бубна / More Capacious than the Organ and Clearer than the Tambourine).

The synthetic forms of the superlative degree «тишайший», «кротчайший», «нижайший», «сладчайший», «горчайший» can be taken as the examples to be the most characteristic and typical, and it is necessary to note that the adjectives «низкий», «горький», «сладкий» are used by Tsvetayeva not in the direct but figurative metaphorical meaning. However, in the verses by Marina Tsvetayeva there is no such bright contrast like «сладчайший» - «горчайший» as in the lyric poetry by Anna Akhmatova [8],. The language of M.I. Tsvetayeva is distinguished, on the other hand, by greater variety of adjectives used in synthetic form of the superlative degree of comparison. The form 

и прикладной лингвистики». - T.1, №4(6), 2015.

«тишайший» is used in the analyzed text three times, the forms «нижайший» and «сладчайший» are used twice each. Thus, the domination like «сладчайший» «горчайший» being inherent in Akhmatova's verses is not observed in the poetry by Tsvetayeva. But a high frequency of using synthetic forms of the superlative in Tsvetayeva can be recognized as a distinguishing feature of Tsvetayeva's style as opposed to, for example, a creative method of Nikolai Gumilyev, in whose works such forms are very rare [10].

A distinctive means of creating expressiveness in Tsvetayeva's lyrics is the use of occasional synthetic forms of superlative degree of comparison of adjectives. Though such forms appear in the adjectives, the semantics of which does not admit of forming the superlative degree of comparison, compare: «Владением бесплотнейшим // Какая разлилась// Россия - в три полотнища!» (Tsvetayeva. Рассвет на рельсах / Dawn on the Rails ).

It is obvious that in the real world one cannot imagine something «more bodiless» or «very (the most) bodiless» in comparison with the other things in the objective reality. Explanatory and Grammar Dictionaries do not also make mention of the presence of the degrees of comparison in adjective «бесплотный» [see: 7; 4]. But the form «бесплотнейший» used in the poetic text is the means of expression of the subjective perception of the objective reality by a lyric heroine, and consequently, by the author.

The present analysis of the language material has shown that the forming prefix «наи-» intensifying the degree of manifestation of a feature is highly frequent in Marina Tsvetayeva's poetry. Of 57 examples of the usage of synthetic forms of the superlative degree of comparison of adjectives, the meaning of the feature in the absolute form of its manifestation is intensified in 6 cases with the help of this prefix, that is, «наи-» is found approximately in $10 \%$ of the considered forms. This indicates a high degree of subjectivity of Tsvetayeva's poetry, peculiarities of the author's association of the world, compare: «Наинасытнейшая рифма// Недр, наинизший тон...» (Tsvetayeva. Емче органа и звонче бубна / More Capacious than the Organ and Clearer than the Tambourine).

As one can see, such the prefix is used even in occasional forms of the superlative degree of comparison of adjectives, being already rather expressive owing to its author's individual character. To compare, one can recall that in two-volume collected works by Anna Akhmatova there only one example of using the prefix «наи-» is found[8], compare: «Из которой глядит тот самый,//
Ставший наигорчайшей драмой,// И еще не оплаканный час» (Akhmtova. Поэма без героя / The Poem without the Hero).

Therefore, it is reasonable to decide that the use of the forms with the prefix «наи-» is one of the characteristic features of M.I. Tsvetayeva's idiostyle, peculiarity of functioning synthetic forms of the superlative degree of comparison of adjectives in the language of the poetess's literary works.

Synthetic form of the superlative degree of comparison of adjectives is found 57 times in the texts of verses, which accounts for approximately 55 $\%$ of the total number of uses of forms of degrees of adjectives in Marina Tsvetayeva's lyric language. The use of a synthetic form of the superlative degree of comparison on the whole is the most peculiar to the author's poetry.

Approximately one third of the total number of the examples of using synthetic form of the superlative degree is constituted by the constructions «synthetic form of the superlative degree + noun in the genitive case with the preposition «uз». Such constructions for the author are obviously important, as the presence of prepositional and case word-form allows to render the absolute degree of manifestation of a feature in a thing brighter, to concentrate attention of the addressee of the message on the highest degree of intensity of a feature. It is by no chance characteristic for Marina Tsvetayeva's lyrics the use of the attributive pronoun «весь» in the form of plural in such constructions, as this pronoun emphasizes that the feature in a thing is manifested in the superlative degree, in spite of the fact that in the world there are good many things having such feature.

The bright means of creating expressiveness in Tsvetayeva's lyrics is the use of occasional synthetic forms of the superlative degree of comparison of adjectives. Though such forms appear in the adjectives, the semantics of which does not admit of forming the superlative degree of comparison. The occasional synthetic forms of the superlative degree of comparison of adjectives constitute rather considerable part of the examples of using synthetic forms of the superlative in the language of Marina Tsvetayeva's poetry.

The present analysis of the language material has shown that the forming prefix «наи-» intensifying the degree of manifestation of a feature is highly frequent in Marina Tsvetayeva's poetry. Of 57 examples of the use of synthetic forms of the superlative degree of comparison of adjectives, the meaning of the feature in the absolute form of its manifestation is intensified in 6 cases with the help of 
this prefix. This prefix is observed in both usual and occasional forms.

The peculiarity of using synthetic forms of the superlative degree of comparison of adjectives in the language of Marina Tsvetayeva's works is the author's endevour to saturate the verse with such forms. The use of the single synthetic form is characteristic for Tsvetayeva, but the examples of realization of these forms in one context are also found rather frequent.

Representing each of the features as the highest by the degree of its manifestation, the author of the verses tries to achieve the maximum of text expressiveness. It is possible to argue that these forms perform a text-forming function, are the means of expressing the category of text coherence.

In the language of Marina Tsvetayeva's lyric works there are far less examples of the use of the analyzed forms as homogeneous parts of the sentence.

It is obvious that the degree of informative value and expressivity of such constructions is lower. On the other hand, the use of the homogeneous parts synthetic forms of the superlative, is attributable to Tsvetayeva's poetry in three cases, when the author characterizes not a thing of the inanimate nature, but a man.

The characteristic technique for Tsvetayeva's poetry is repetition of a synthetic form within the framework of one context, grammatical and lexical repetition. Various types of repetition is the means of expression of expressivity and intensity of feature manifestation. A thing in the verse is a possessor of the feature in the superlative degree of its manifestation compared with the other views which are also the possessors of this feature but in less degree of its manifestation. This degree of feature manifestation is perceived by the addressee of the message much brighter and better.

It also should be pointed out that most of the adjectives used in synthetic form of the superlative degree in the analyzed verses denote not the external features but the internal features of a thing connected with intellectual, spiritual, psychological constituents of human life and his perception of the objective world. Representations of the external features of a thing expressed by the adjective in synthetic form of the superlative degree of comparison are very rare to be found in the texts of Marina Tsvetayeva's verses.

It is also necessary to note that characteristic feature for Tsvetayeva's poetry is the presence of synthetic forms of the superlative degree of adjectives, the semantics of which is connected with the state of stillness, calm, meekness, fragility.

The most characteristic and typical examples are the synthetic forms of the superlative degree «тишайший», «кротчайший», «нижайший», «сладчайший», «горчайший», though it is essential to note that the adjectives «низкий», «горький», «сладкий» are used by Tsvetayeva not in the direct but figurative metaphorical sense. The form «тишайший» is used three times in the analyzed texts, the forms «нижайший» and «сладчайший» are used two times each. The dominance of «сладчайший» - «горчайший» which is inherent in Akhmatova'a verses is not observed in Tsvetayeva's verses.

Thus, on the basis of the analysis of functioning of synthetic forms of the superlative degree one can argue that the superlative degree of adjectives for the author is one of the most preferable linguistic means of expressing intensity and expressiveness.

\section{References}

1. Galkina-Fedorchuk E.N. Contemporary Russian language. Part 1. Phonetics. Lexicology. Word formation. Moscow, 1958.

2. Gridin V.N. Expressiveness // Linguistics / Ch. Ed. V.N. Yartseva. Moscow, 1998.

3. Zhernovaya O.R. Comparatives as means of intensification of the statements in the feature text // Journal of the Nizhny Novgorod N.I. Lobachevsky State University. Vol. № 1. 2010. P. 222-228.

4. Zaliznyak A.A. Russian nominal inflection. Moscow, 1967.

5. Milevskaya T.V. Connectivity as a category of discourse and text (cognitive-functional and communicative-pragmatic aspects).The thesis of Doctor of Philology. Rostov-on-the Don, 2003.

6. Miloslavskii I.G. Morphological categories of the modern Russian language. Moscow, 1981.

7. Ozhegov S.I., Shvedova N.Y. Explanatory dictionary of the Russian language. Moscow, 2003.

8. Panteleyev A.F, Dolmatova A.S. Some remarks of the superlatives in the language of a poetry of A.A. Akhmatova // Language and communication: Collection of scientific works// Ed. V.V. Boguslawska. Volume 8.Rostov-on-the Don: IC DSTU, 2014. P. 76 - 82.

9. Fortuna O.N. Multilevel means of expression and intensity of negation and their specific functions in the language of prose of A.P Chekhov. (1890-1900 years.). Author's abstract... The thesis of Doctor of Philology. Rostov-on-the Don, 2001.

10. Panteleyev Andrew Felixovitch, Dolmatova Anna Sergeyevna. Superlative as the means of forming the Expression (expressivity) in poetry of Russian acmeism //Austrian Journal of Humanities and Social Science. Vienna, 2015. № $1-2$. P. $168-171$. 